\title{
CALCIUM AND PHOSPHORUS META- BOLISM IN SOME OLDER CHILDREN ON MIXED DIET INCLUDING A LARGE OR A SMALL QUANTITY OF MILK
}

BY

ANGELIA M. COURTNEY, B.A., and ALAN BROWN, M.B.

(From the Sub-Department of Pædiatrics, University of Toronto, and the Hospital for Sick Children, Toronto.)

In view of the frequently observed stimulating effect on growth of large amounts of milk included in the mixed diet of older children, it was thought worth while some years since to determine the calcium and phosphorus excretion and retention during pericds of feeding with high milk and low milk diets. The observations were completed shortly before the appearance of the valuable contribution by Sherman and Hawley ${ }^{1}$ on calcium and phosphorus metabolism in childhood. Our results seemed not altogether consistent, and as Sherman and Hawley's work covered the ground far more completely than ours, these results were set aside for the time.

A recent consideration of the data has revealed some interesting relationships among groups of the children studied, and the findings seem to have a more instructive aspect than was at first apparent.

Beyond demonstrating clearly that the low milk diets contained too little calcium and phosphorus to provide for retention of those elements, at least during the period of observation, there were no clear cut differences in the findings for the two dietary groups, that on a high milk and that on a low milk mixed diet. On the contrary, the values found for each dietary group fall into two distinctly different classes, making altogether four groups of two children each, and in each group the calcium and phosphorus metabolism appears to be strikingly similar for the two making up the group, while distinctly different from that of the other groups. An account of the conditions of the study will precede a discussion of the findings.

The subjects of the study were two girls, respectively 5 years and 10 months, and 6 years and 2 months, and two boys, 9 years and 5 years, who were given a suitable mixed diet, modified to include a large amount of milk, partly incooked items of the diet, partly given as drink ; also two girls, 5 years and 10 months, and $9 \frac{1}{2}$ years respectively, and two boys 8 years and 2 months and $13 \frac{1}{4}$ years, who were given a mixed diet containing very little milk, but suitable as regards caloric value and percentage composition. The girls were all surgical cases recovered after treatment for congenital disclocation of the hip or infantile paralysis. One in the pair forming Group 4 was somewhat underweight. The 
boys were of various conditions : one somewhat underweight after recovery from tuberculous glands, one a mental defective physically normal, one an epileptic free from attacks at the time of observation, fairly well-nourished and with normal sugar tolerance, the fourth a congenital syphilitic undersized but in fairly good condition at the time. Serum calcium and phosphorus were determined in seven of the eight children and were in all cases normal.

The four girls were under observation together, two on each kind of diet, and immediately after the four boys were studied under practically the same conditions as the girls. The corresponding menus for girls and boys were as nearly as possible the same. A variation in kind of cereal, vegetable, meat and cooked fruit was made from day to day in accordance with hospital routine with both boys and girls. The high milk diet was as follows :-

Breakfast: Orange, cereal, sugar, milk, bread and butter.

Dinner: Cream soup, potato, one other vegetable, custard, milk.

Supper: Cereal, sugar, milk, junket, bread and butter.

This diet included 32 ounces of milk besides that in cream soup, custard, and junket. The girls in Group 1 refused part of the milk and cream soup, and both boys refused part of the cream soup.

The low milk diet was as follows :-

Breakfast : Orange, cereal, sugar, milk, bread and butter, lemonade.

Dinner: Meat, potato, another vegetable, jelly, orangeade.

Supper: Egg, cooked fruit, bread and butter, lemonade.

This diet included only four ounces of milk, taken with the cereal at breakfast. The weather being warm the fruit juices were an acceptable substitute for milk. On both diets the boys usually took more bread and butter than the girls. The wide difference in the two diets in milk content necessitated making important differences in the other items, particularly in order to bring up the protein and fat content of the low milk diet. With all modifications practicable, the fat intake on the low milk diet was much lower than on the high milk one, for the children on low milk intake would not take the extra butter offered, while those on high milk intake would not take skim milk. Obtaining ideal experimental conditions was made secondary to giving diets which would be taken with appetite and no undue urging. This was especially difficult as the children had been for some time in hospital, took little exercise and the weather was warm and debilitating.

The children were given their respective diets for a short preliminary period. The exact measurement of the intake was carried out for five days, and a representative sample corresponding to the food taken by each child was reserved for four days to make up a composite collection for the period of analysis. The separate collection for each child was necessary because of slight, or in one case considerable, variation in the amounts taken. Fæces and urine were collected in twenty-four hour quantities, the fæces for the first day and urine for the fifth being discarded. When it seemed necessary in order to insure a regular excretion of fæces, a plain water enema was given. The analyses of urine and fæces were made on composite samples for each child. Standard gravimetric methods for determining calcium, magnesium and phosphorus were 
used. Fat was estimated by a modification of the Roesse-Gottlieb method. No changes in physical condition of the children were noted during the observation period.

The findings have been arranged in two tables giving values for intake and fæces content of fat, calcium, magnesium and phosphorus, and urinary and fæcal excretion and retention of calcium and phosphorus. The children are classified in these tables in four groups, 1 and 2 on the high milk diet, and 3 and 4 on the low milk. On the high milk intake one girl and one boy form one group and the other boy and other girl another group, the two of each group showing similar conditions of excretion and retention of calcium and phosphorus. On the low milk diet the two boys form one pair and the two girls another pair, the two of a pair showing similar metabolism of calcium and phosphorus. Except in Group 1 the intake of the two children of a group corresponds fairly closely. In Group 1 the girl had a poor appetite and took considerably less milk than the other children on the high milk diet. The girls forming Grouj; 4 took slightly less food than the boys or the same diet.

The question arises whether the different assimilation of calcium and phosphorus by these children on similar diets can be explained by differences in their condition of health.

The girls were all surgical cases, well-developed and well-nourished, except Hilda, who was thin and somewhat emaciated. Agnes had been receiving treatment for infantile paralysis, the other three for congenital dislocation of the hip. There is more reason to consider three of the boys not quite normal, though none was ill at the time. Tommy had recovered from tuberculous glands but suffered from endocarditis and mediastinal tuberculosis and was underweight. Ivan was an epileptic but had been without seizures for a considerable period. He was well-nourished. Billy was a congenital syphilitic and had paroxysmal hæmoglobinuria, but though thin and undernourished, was well at the time, not having had a chill for more than a month. Abe, the fourth boy, was mentally subnormal but physically normal.

The theory might be advanced that the intake of Regina in Group 1 was more nearly ideal than the greater intake of the other three children on the high milk diet, but that under-nourished and tuberculous Tommy needed and assimilated the larger intake, the normal Abe and Agnes did not. This reasoning, however, cannot be applied to Groups 3 and 4, as one of each of these groups was distinctly better nourished than the other, but the diet of the two of each pair was almost identical.

\section{Discussion.}

Groups 1 and 2, on large calcium and phosphorus intake :- The calcium intake is larger than Sherman and Hawley's ${ }^{1}$ estimate of the requirement of children, 1 grm. calcium a day, equal to 1.4 grm. calcium oxide; but neither the intake of calcium nor that of phosphorus can be considered excessive, according to the study of Orr and his fellow-workers. ${ }^{2}$

Group 1 shows a much smaller excretion of both calcium and phosphorus in the fæces and in urine than Group 2 ; a much greater retention of calcium 
and of phosphorus, than Group 2 ; and about the same excretion of phosphorus in fæces and in urine or more in urine.

Group 2 shows greater excretion of fat and total salts as well as of calcium and of phosphorus than Group 1, and greater excretion of phosphorus in fæces than in urine.

Groups 3 and 4, on low intake of calcium and of phosphorus, extremely low of calcium :-

Group 3 shows a much smaller excretion of calcium in the fæces and distinctly less of phosphorus than Group 4 ; less calcium in the urine but very much more phosphorus in the urine than Group 4; a near equilibrium as to retention of calcium and slight negative balance of phosphorus ; and more phosphorus in urine than in fæces.

Group 4 shows a large negative balance of calcium and smaller of phosphorus ; and more phosphorus in fæces than in urine.

The difference in calcium and phosphorus metabolism between Groups 3 and 4 on low intake of calcium and phosphorus seems to be more or less parallel with that between Groups 1 and 2 on the high intake, but there is a striking difference between the high and low groups in respect to excretion of phosphorus in the urine. Group 4 on the low intake with greater fæcal excretion of phosphorus shows greatly reduced urinary excretion, while Group 3 has much more in the urine than in the fæces. On the other hand on the high intake, in Group 2 with greater fæcal excretion of phosphorus than in Group 1, there is also greater urinary phosphorus excretion.

In the entire lack of data concerning acidity conditions, particularly total excretion of acids and bases through fæces and urine, an attempt to explain these differences in calcium and phosphorus metabolism on practically the same diet is mainly theorizing. It is advanced by several writers, among whom may be mentioned Telfer ${ }^{4}, \mathrm{Orr}^{2}$, Chaney and Blunt ${ }^{5}$, and Bergeim ${ }^{6}$, that too little acid in the beginning of the small intestine interferes with absorption of the calcium and phosphorus of the intake, particularly of the calcium, and as a result calcium and phosphorus pass into the large intestine as insoluble calcium phosphate. That this is not the whole story is evident from the condition shown in Groups 3 and 4, where in the one group the fæcal calcium is nearly equal to the entire intake of calcium and in the other group far surpasses that of the intake. In these two groups, especially in Group 4, there must have been a considerable excretion of calcium into the large intestine from the body. Some studies on the intestinal contents of rats made in this laboratory ${ }^{3}$ indicate that salcium is largely absorbed from the small intestine and excreted into the large, into the cæcum in the rats.

That fat excretion and need of calcium for formation of calcium soaps plays a small part in cares of excessive calcium excretion in the fæces is well shown in Table 1. The highest fat excretion was in Group 2. Allowing for a considerably greater proportion of soap fat in Group 2 than in Group 1, at the most the difference in soap fat excretion between Groups 1 and 2 could not have been as great as 2 grm., and probably was far less than that. Two 
TABLE 1.

Composition of Food and of Feces. Daily average.

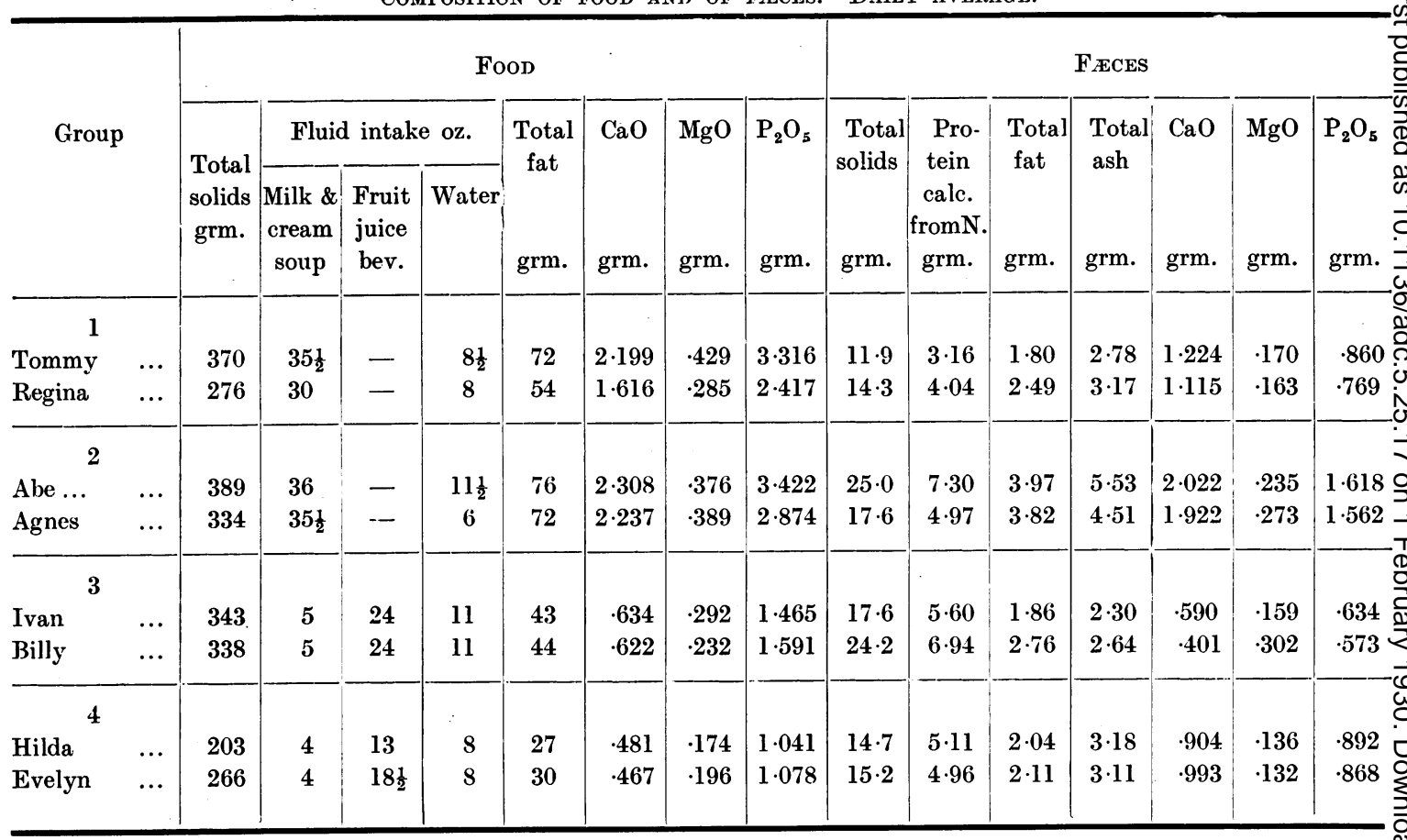

TABLE 2.

Excretion and retention of calcium and phosphorus. Daily average.

\begin{tabular}{|c|c|c|c|c|c|c|c|c|c|c|c|c|c|c|}
\hline \multirow{4}{*}{\multicolumn{2}{|c|}{ Group }} & & \multirow{2}{*}{\multicolumn{2}{|c|}{$\begin{array}{l}\text { Excretion } \\
\text { in urine }\end{array}$}} & \multirow{3}{*}{$\begin{array}{c}\text { Ratio } \\
\text { fæcal to } \\
\text { urinary } \\
\text { excretion } \\
\text { of } \mathrm{P}_{2} \mathrm{O}_{5}\end{array}$} & \multirow{4}{*}{$\begin{array}{c}\text { Sum of } \\
\mathrm{CaO}, \mathrm{MgO} \\
\& \mathrm{P}_{2} \mathrm{O}_{5} \\
\text { excretion } \\
\text { in fæces* } \\
\text { grm. }\end{array}$} & \multicolumn{4}{|c|}{ Excretion in fæces and urine } & \multicolumn{4}{|c|}{ Retention } \\
\hline & & & & & & & \multirow{2}{*}{\multicolumn{2}{|c|}{$\mathrm{CaO}$}} & \multirow{2}{*}{\multicolumn{2}{|c|}{$\mathrm{P}_{2} \mathrm{O}_{5}$}} & \multirow{2}{*}{\multicolumn{2}{|c|}{$\mathrm{CaO}$}} & \multirow{2}{*}{\multicolumn{2}{|c|}{$\mathrm{P}_{2} \mathrm{O}_{5}$}} \\
\hline & & & $\mathrm{CaO}$ & $\mathrm{P}_{2} \mathrm{O}_{5}$ & & & & & & & & & & \\
\hline & & & grm. & grm. & & & grm. & $\begin{array}{c}\% \text { of } \\
\text { intake }\end{array}$ & grm. & $\begin{array}{c}\% \text { of } \\
\text { intake }\end{array}$ & grm. & $\begin{array}{l}\% \text { of } \\
\text { intake }\end{array}$ & grm. & $\begin{array}{l}\% \text { of } \\
\text { intake }\end{array}$ \\
\hline $\begin{array}{l}\text { Tommy } \\
\text { Regina }\end{array}$ & $\begin{array}{l}1 \\
\ldots \\
\ldots\end{array}$ & $\begin{array}{l}\cdots \\
\ldots\end{array}$ & $\begin{array}{l}\cdot 105 \\
.069\end{array}$ & $\begin{array}{r}1.050 \\
.069\end{array}$ & $\begin{array}{r}.82 \\
1.08\end{array}$ & $\begin{array}{l}2 \cdot 25 \\
2 \cdot 05\end{array}$ & $\begin{array}{l}1 \cdot 33 \\
1 \cdot 18\end{array}$ & $\begin{array}{l}60 \cdot 3 \\
73 \cdot 1\end{array}$ & $\begin{array}{l}1.91 \\
1.48\end{array}$ & $\begin{array}{l}57 \cdot 6 \\
61 \cdot 2\end{array}$ & $\begin{array}{l}\cdot 871 \\
\cdot 431\end{array}$ & $\begin{array}{l}39 \cdot 6 \\
26 \cdot 7\end{array}$ & $\begin{array}{r}1.407 \\
.935\end{array}$ & $\begin{array}{l}42 \cdot 4 \\
38 \cdot 7\end{array}$ \\
\hline $\begin{array}{l}\text { Abe ... } \\
\text { Agnes }\end{array}$ & $\begin{array}{l}2 \\
\ldots \\
\ldots\end{array}$ & $\begin{array}{l}\cdots \\
\cdots\end{array}$ & $\begin{array}{c}\cdot 170 \\
\cdot 259\end{array}$ & $\begin{array}{l}1.294 \\
1.091\end{array}$ & $\begin{array}{l}1 \cdot 25 \\
1 \cdot 43\end{array}$ & $\begin{array}{l}3 \cdot 87 \\
3 \cdot 76\end{array}$ & $\begin{array}{l}2 \cdot 19 \\
2 \cdot 18\end{array}$ & $\begin{array}{l}95 \cdot 0 \\
97 \cdot 5\end{array}$ & $\begin{array}{l}2 \cdot 91 \\
2 \cdot 65\end{array}$ & $\begin{array}{l}85 \cdot 1 \\
92 \cdot 3\end{array}$ & $\begin{array}{l}\cdot 116 \\
\cdot 056\end{array}$ & $\begin{array}{l}5 \cdot 0 \\
2 \cdot 5\end{array}$ & $\begin{array}{l}.511 \\
.221\end{array}$ & $\begin{array}{r}14.9 \\
7.7\end{array}$ \\
\hline $\begin{array}{l}\text { Ivan } \\
\text { Billy }\end{array}$ & $\begin{array}{l}3 \\
\ldots \\
\ldots\end{array}$ & $\cdots$ & $\begin{array}{l}.081 \\
\cdot 157\end{array}$ & $\begin{array}{r}.920 \\
1 \cdot 135\end{array}$ & $\begin{array}{l}.69 \\
.50\end{array}$ & $\begin{array}{l}1 \cdot 38 \\
1 \cdot 28\end{array}$ & $\begin{array}{l}.671 \\
.558\end{array}$ & $\begin{array}{r}106 \cdot 1 \\
89 \cdot 8\end{array}$ & $\begin{array}{l}1 \cdot 55 \\
1 \cdot 71\end{array}$ & $\begin{array}{l}106 \cdot 1 \\
107 \cdot 3\end{array}$ & $\begin{array}{l}\cdot 037 \\
\cdot 063\end{array}$ & $\overline{10 \cdot 2}$ & $\begin{array}{l}\cdot 089 \\
\cdot 118\end{array}$ & - \\
\hline $\begin{array}{l}\text { Hilda } \\
\text { Evelyn }\end{array}$ & $\begin{array}{l}4 \\
\ldots \\
\ldots\end{array}$ & $\cdots$ & $\begin{array}{l}\cdot 088 \\
\cdot 230\end{array}$ & $\begin{array}{l}\cdot 370 \\
\cdot 491\end{array}$ & $\begin{array}{l}2 \cdot 41 \\
1 \cdot 77\end{array}$ & $\begin{array}{l}1.93 \\
1.99\end{array}$ & $\begin{array}{c}.992 \\
1 \cdot 22\end{array}$ & $\begin{array}{l}206 \cdot 3 \\
261 \cdot 8\end{array}$ & $\begin{array}{l}1 \cdot 26 \\
1 \cdot 36\end{array}$ & $\begin{array}{l}121 \cdot 3 \\
126 \cdot 0\end{array}$ & $\begin{array}{l}.512 \\
.755\end{array}$ & - & $\begin{array}{l}\cdot 222 \\
\cdot 281\end{array}$ & - \\
\hline
\end{tabular}


grammes of soap fat would require only about $0 \cdot 2 \mathrm{grm}$. of calcium oxide to form soap, which amount is seen to be insignificant in comparison with the large difference in calcium excretion between Groups 1 and 2 .

The large urinary excretion of phosphorus in Group 3 is difficult to understand in company with so small an intake of phosphorus, especially when resulting in a slight negative balance. However, the greater intake in Group 3 than in Group 4 made it possible to allow an ordinary urinary excretion in Group 3 and yet hold practically phosphorus equilibrium, while in Group 4 the lower intake and greater fæcal output were accompanied by greatly reduced urinary excretion as well as phosphorus deficit.

\section{Summary.}

1. Two boys and two girls were fed mixed diets including a large quantity of milk, and two other boys and two other girls a corresponding diet containing very little milk. Food, urine and fæces were collected quantitatively for four day periods and analysis were made for fat, calcium, magnesium and phosphorus in order to determine the excretion and retention of these constituents.

2. The low milk diets, even with inclusion of eggs and vegetables, were found to provide far too little calcium and phosphorus for the necessary retention of these elements.

3. The results were found to fall into two distinct groups for each kind of diet. In one group on each calcium and phosphorus level the excretion of calcium and phosphorus, except urinary phosphorus, on the low intake, was much less than in the other on the same diet and the retention correspondingly better. The large urinary excretion of phosphorus in Group 3 is difficult to explain.

4. These observations afford evidence that children on the same diet and apparently in equally good condition can on occasion differ so materially in their metabolic processes that one may lose through the fæces far larger amounts of calcium and phosphorus than the other, even to the point of suffering a serious loss to the body when the intake of these elements is low.

\section{REFERENCES.}

1. Sherman, H. C., \& Hawley, E., J. Biol. Chem., N.Y., 1922, LIII, 375.

2. Orr, W. J., Holt, L. E. Jr., Wilkins, L., \& Boone, F. H., Am. J. Dis. Child., Chic., 1924, XXVIII, 574.

3. Courtney, A. M., Tisdall, F. F., \& Brown, A., Can. Med. Ass. J., Montreal, 1928, XIX, 559.

4. Telfer, S. V., Quart. J. Med., Oxford, 1923, XXIV, 245.

5. Chaney, M. S., \& Blunt, K., J. Biol. Chem., N.Y., 1925, LXVI, 829.

6. Bergein, C., J. Biol. Chem., N.Y., 1926, LXX, 29. 